\title{
APPLYING WEIGHT GAIN IN Pomacea lineata (SPIX 1824) (MOLLUSCA: PROSOBRANCHIA) AS A MEASURE OF HERBICIDE TOXICITY
}

\author{
COLER, R. A. ${ }^{1}$, COLER, R. R. ${ }^{2}$, FELIZARDO, E. K. G. ${ }^{1}$ and WATANABE, T. ${ }^{1}$ \\ ${ }^{1}$ Programa Regional de Pós-Graduação em Desenvolvimento e Meio Ambiente, \\ Universidade Federal da Paraíba, C.P. 5122, CEP 58051-970, João Pessoa, PB, Brazil \\ ${ }^{2}$ Iscatech Entomological Services, Riverside, CA 92504, USA \\ Correspondence to: Takako Watanabe, Programa Regional de Pós-Graduação em Desenvolvimento e Meio Ambiente, \\ Universidade Federal da Paraíba, C.P. 5122, CEP 58051-970, João Pessoa, PB, Brazil, \\ e-mail: t.watanabe@globo.com
}

Received December 14, 2003 - Accepted March 10, 2004 - Distributed November 30, 2005

\begin{abstract}
Pomacea lineata, an extremely ubiquitous snail and pest to rice farmers throughout Asia, holds promise as a valuable resource for monitoring water quality in northeast Brazil. In this paper, we present data demonstrating the rate of weight gain in P. lineata neonates as a consistent measure of the stress imposed by sublethal concentrations of the herbicides Paraquat and Round-up. Our secondary agenda is to demonstrate the feasibility of incorporating bioassay into the standard municipal and state procedure of monitoring water quality. Growth data to assess chronic toxicity were generated in experiments of four and four, eight, twelve and sixteen days for Paraquat and Round-up, respectively. We estimated a $96 \mathrm{~h}$ no observed effect concentration (NOEC) and lowest observed effect concentration (LOEC) for Paraquat of 0.12 and $0.25 \mathrm{mg} / \mathrm{L}$. The $96 \mathrm{~h}$ Round-up data yielded NOEC and LOEC values, respectively, of 0.25 and $0.5 \mathrm{mg} / \mathrm{L}$. All concentrations of Round-up tested for the $192 \mathrm{~h}$ exposure yielded significantly lower growth than the control. Consequently, no NOEC could be derived. The LOEC was $<0.12 \mathrm{mg} / \mathrm{L}$. Furthermore, there was no mortality during the test. At the lowest concentrations of Paraquat tested $(0.005 \mathrm{mg} / \mathrm{L})$ there was a significant increase in growth compared with the controls, suggesting a hormetic effect.
\end{abstract}

Keywords: biomonitoring, herbicide pollution, weight gain, toxicity.

\section{RESUMO \\ Aplicando o ganho de peso em Pomacea lineata (Spix, 1824) (Mollusca: Prosobranchia) como uma medida de toxicidade a herbicida}

Pomacea lineata, um molusco amplamente distribuído e considerado como peste em plantações de arroz no Oriente, pode ser considerado como um valioso recurso para monitorar a qualidade da água no Nordeste do Brasil. Neste trabalho, apresentamos dados que demonstram que o incremento de peso em moluscos neonatos é uma medida consistente que responde eficientemente ao estresse imposto por concentrações tóxicas subletais dos herbicidas Paraquat e Round-up. Os resultados de crescimento para avaliar a toxicidade crônica foram obtidos em experimentos de quatro e quatro, oito, doze e dezesseis dias para Paraquat e Round-up, respectivamente. A maior concentração de efeito não observado (NOEC) e a menor concentração de efeito observado (LOEC) para Paraquat, após 96 horas, foram respectivamente de 0,12 e $0,25 \mathrm{mg} / \mathrm{L}$. Para o Round-up, os valores de NOEC e LOEC estimados foram respectivamente de 0,25 e $0,5 \mathrm{mg} / \mathrm{L}$. Todas as concentrações de Round-up testadas após 192 horas de exposição provocaram diminuições nas taxas de crescimento, sendo significativamente diferentes do controle. Conseqüentemente não pode ser estimado o valor de NOEC. O valor de LOEC foi menor do que $0,12 \mathrm{mg} / \mathrm{L}$. Além disso, 
não houve nenhuma mortalidade durante o teste. Por conseguinte, nenhum NOEC pôde ser derivado e o LOEC era $<0,12 \mathrm{mg} / \mathrm{L}$. Para as mais baixas concentrações de Paraquat testadas $(0,005 \mathrm{mg} / \mathrm{L})$, houve um aumento do crescimento que foi significativamente maior que o controle, sugerindo a ocorrência de um efeito hormético.

Palavras-chave: biomonitoramento, poluição por herbicida, toxicidade, ganho de peso.

\section{INTRODUCTION}

To date there have been no state or federally sponsored water pollution surveys, nor are there adequate quality control/assurance measures in place to regulate pesticide applications. Although there are active state and federal water pollution control agencies, the parameters they routinely apply to assess water quality (turbidity, B.O.D., D.O., alkalinity, acidity, $\mathrm{pH}$, coliforms, etc.) do not directly measure toxicity. In this regard, ELISA assays have been developed for some of the herbicides (Clegg et al., 1999, 2001). While these assays have proved accurate, rapid and more cost-effective than conventional chromatographic analysis, the methods' sophistication and cost preclude their routine application throughout the region.

A regional water quality survey program is strongly recommended: an early-warning protocol to rapidly identify hazards to the environment and to public health. Lack of financial resources in the Northeast, however, leaves biomonitoring (benthic macroinvertebrate surveys and bioassays) as our only means for quality assurance. Biotic surveys, however, are based on species identification and the taxonomic keys published for the region are incomplete. The alternative is a bioassay, one that affords a rapid winnowing of suspect samples, a kind of a triage that rapidly provides a yes or no answer to a broad range of toxicants.

We may have found such a tool in Pomacea lineata four-day-old neonates, which are readily available and sensitive. Mature females deposit egg masses of 400-600 ova on emergent vegetation, structures and rocks throughout the shallows where they can be readily retrieved. The numbers hatched are sufficient to permit replicated comparisons of selected concentrations among siblings. The methodology is simple, rapid and inexpensive, requiring only a semianalytical balance and the standard complement of laboratory glassware. Maximum allowable toxicant concentrations
(MATC), derived from the geometric average of the no observed effect concentration (NOEC) and the lowest observed effect concentration (LOEC) determinations, as well as 50\% lethal concentrations (LC50s), can be readily generated in regional laboratories. Melo (2000) has applied this protocol to measure toxicity in the factory outfalls of Toalia and Norfil in the Gramame River Watershed, Conde. He obtained 96 h LC50's at less than $30 \%$ effluent concentrations. During the summer, mortality was also observed within $10 \mathrm{~m}$ of the outfall in the river.

In the present research we demonstrate the method applied to the herbicides Gramoxone 200 (Paraquat (1,1'-dimethy 1-4,4'- bipyridyldiylium dichloride - $200 \mathrm{~g} / \mathrm{L}$ ) and Round-up (N - (phosphor methyl) glycine (isopropyl amine salt) - $480 \mathrm{~g} / \mathrm{L}$ ). These are the most extensively and frequently applied herbicides in the littoral and semi-arid zones (Gonçalves et al., 1992). The procedure is designed to permit implementation without additional investment in equipment, space, formal education or manpower. As such, this method of monitoring water quality is offered as an expedient, a strategy to reduce demands on limited laboratory analytical resources, yet still provide the capacity to monitor water quality through toxicity testing in northeastern Brazil.

\section{MATERIAL AND METHODS}

The test specimens were treated as described by Melo et al. (2000), except that the neonates were maintained on a feeding regime and the endpoints adopted were weight gain as percent increase over initial weight instead of as percent survival. The ration consisted of a mixture of equal portions by weight of ground fish, wheat, soy and corn flour steamed, agglutinated with mandioca flour, dried and pulverized. The food was sprinkled in excess on the surface of each replicate beaker 4 hours before its daily replacement with acid-rinsed glassware and fresh test solutions. During this 
interval, immobile organisms that failed to respond to $5 \mathrm{~min}$ exposure to intense light and pricking were removed to minimize detrital pesticide adsorption and degradation of water quality. The collective weight of each treatment replicate (15 individuals) was determined at the beginning and end of each experiment, which, was 4 days for Paraquat and 4 and 8 days for Round-up. (When comparing growth rates, the entire experiment has to be confined to a single egg mass. Comparisons must be made with kin as controls because growth rates and vigor between, but not among, egg masses vary greatly. Every egg mass, consequently, requires its own control.)

Subsequently, as a fine tuning measure to assess Round-up toxicity, we increased the replicate number to 6 , exposure intervals to 4 , 8, 12 and 16 days and concentrations to: 0.06, $0.12,0.24$ and $0.48 \mathrm{mg} / \mathrm{L}$. The percent increase in weight over the initial weight was calculated for each replicate of each treatment and confidence intervals derived. To determine the accuracy of the weighing procedure, we randomly selected 15 neonates and weighed them 10 consecutive times, each time returning them to the water, retrieving them, blotting them dry and weighing them. The average weight, confidence interval and coefficient of variation were, respectively, $0.0116 \mathrm{~g}$, 0.00083 and $2.3 \%$. Fifteen four-day-old neonates were used for each treatment replicate (Paraquat $(\mathrm{n}=4)$ and Round-up ( $=5$ and 6). Significance was derived from confidence intervals. The herbicide concentration was regressed against percent weight gain to determine the extent that growth inhibition was a function of herbicide concentration. Statistics were based on nominal concentrations because the laboratory staff of the sertão and semi-arid regions (for whom this protocol was developed) are generally restricted to the standard facilities of a wet laboratory and do not have the analytical resources of those located in large population centers.

The protocol described here is a modification of the procedures promulgated by the USEPA for use by industries and municipalities in whole effluent toxicity (WET) testing. To assume that our candidate can serve as the universal "alarm", however, is not too different from the search in the $60 \mathrm{~s}$ for the universal indicator organism. Consequently, we are exploring the potential of other organisms such as Macrobrachium amazonicum (Coler et al., 1999) and Selanastrum capricornutum (Rocha et al., 1998) to respond to other pollutant families (trace metals, polycyclic aromatic hydrocarbons).

\section{RESULTS AND DISCUSSION}

Previously we described a procedure for routinely identifying acute toxicity in suspect water samples using starved neonates of the amphibious gastropod Pomacea lineata (Melo et al., 2000). Upon attempting to assess the toxicity of the relatively benign herbicide Round-up, however, a slightly toxic class 3 pesticide (based on the E.P.A. classification of acute toxicity classes: 1 - highly toxic and 4 - nontoxic), we were unable to find a clear distinction between mortality due to the herbicide and that due to starvation. The mortality among the controls exceeded $10 \%$ in each of the 5 replicates. Consequently, we sought other measures to gauge the organism's sensitivity. One such tactic was to initiate feeding, though it would appear that feeding an already resistant species would make it yet more capable of mobilizing some homeostatic mechanism, thus rendering it even less sensitive to stress. The choice, however, proved to be serendipitous because the impact of the toxicant on percent increase in weight yielded a finer resolution of response than mortality. Statistically significant differences in weight gain are not normally generated by benthic macroinvertebrates in four days when the toxicant is not virulent. The fact that the response was achieved in acute toxicity time frames makes the protocol particularly pertinent to water monitoring in northeastern Brazil, where there is an urgent need for the rapid generation of base line toxicity data.

This region, comprising 9 states and beset by chronic drought and poverty, has a limited capacity to respond to environmental / public health crises. Of the $188.7 \mathrm{~cm}$ of annual rainfall (10 year average), $28.7 \mathrm{~cm},(15 \%)$ occurs from August through April (Medeiros et al., 2001). Virtually all water derives from some 70,000 impoundments with surface areas in excess of 1 hectare (Watanabe et al., 1999). Invariably they are exploited jointly as sources for irrigation and potable water, without regard for ecological consequences or public health concerns. 
Sugar cane, the principal crop of the littoral zone, occupies about $95 \%$ of the cultivated land within the watershed (Medeiros et al., 2001). The herbicide almost exclusively applied is Paraquat (Gonçalves et al., 1992). Further into the interior, however, garden vegetables are grown and the herbicide generally favored is Round-up. Substantially, all of the arable land within the reservoir watershed is farmed. The exploitation of the basin generally progresses along a consistent sequence during the dry season. Cultivation, fertilization and herbicide applications follow the receding water level during this period of scant rainfall as the reservoirs shrink to a fraction of their capacity. With the advent of the rains, but before dilution reduces the toxicity, excessive runoff and flooding, in concert with herbicide applications and fertilizer enrichment, contribute to foster a eutrophied, marginal environment dominated by cyanobacteria (Ceballos et al., 1995). During the dry season, river flow in the Gramame Watershed consists totally of reservoir hypolimnion. River water quality and quantity, then, are dominated upstream by reservoir use (irrigation and municipal drawdown) and downstream by pollution from industrial effluents (Toalia and Norfil). Variations on this theme occur throughout the littoral zone of Brazil's Northeast.

A comparison of the previous research where data were generated by testing starved individuals (Melo et al., 2000) with this current study reveals some interesting relationships. The starved treatment yielded time-independent LOEC and
NOEC values of 0.12 and $0.07 \mathrm{mg} / \mathrm{L}$, respectively. In the present feeding regime, the respective values are 0.25 and $0.12 \mathrm{mg} / \mathrm{L}$. The agreement between the two endpoints (death and growth) is noteworthy when considering that the neonates were exposed to the same range of concentrations for 15 as opposed to only 4 days (respectively). Confidence intervals of the 0.07 (survival) (Melo et al., 2000) and the 0.05 (growth) dilutions overlap with those of the control in the two treatments and appear to be good approximations of the NOEC.

Pomacea, when exposed to Paraquat at lower concentrations $(0.005 \mathrm{mg} / \mathrm{L})$, appears to consistently overcompensate with heightened growth rates that are statistically significant (Table 1). According to Calabrese \& Baldwin (1993) such responses might describe the mechanism for hormesis. There is an insufficient database, however, to support anything but speculation. The least convoluted scenario would be that the lower concentrations allow for the mobilization of some homeostatic mechanism through the induction of an enzyme(s) with an attendant over compensation response (E. J. Calabrese, pers. com.). Regardless of how the nonlinear response is interpreted, this method holds promise as an early warning alarm for herbicide and effluent outfall toxicity (Melo, 2000). Extrapolating from Melo's 4 day acute toxicity data would yield an EC50 of $0.7 \mathrm{mg} / \mathrm{L}$ for Paraquat (effective concentration that reduces some indicated life process \{in this instance, growth $\}$ by $50 \%$ ). This concentration caused $100 \%$ mortality in 6 days. Historically, the EC50 has been perceived as an

TABLE 1

AVERAGE percent increase in weight with confidence intervals (CI) of Pomacea lineata neonates after 4 and 8 days' exposure to recommended concentrations of Round-up and Paraquat (15 individuals per treatment). Asterisk denotes significant difference $(p<0.05 \%)$ from the control.

\begin{tabular}{|c|c|c|c|c|c|c|c|}
\hline \multicolumn{5}{|c|}{ Round-up } & \multicolumn{3}{|c|}{ Paraquat } \\
\hline \multirow{2}{*}{$\begin{array}{c}\text { Concentration } \\
(\mathrm{mg} / \mathrm{L})\end{array}$} & \multicolumn{2}{|c|}{4 days } & \multicolumn{2}{|c|}{8 days } & \multirow{2}{*}{$\begin{array}{c}\text { Concentration } \\
(\mathrm{mg} / \mathrm{L})\end{array}$} & \multicolumn{2}{|c|}{4 days } \\
\hline & $\begin{array}{c}\text { Average } \\
(\%)\end{array}$ & CI & $\begin{array}{c}\text { Average } \\
(\%)\end{array}$ & CI & & $\begin{array}{c}\text { Average } \\
(\%)\end{array}$ & CI \\
\hline 0.00 & 36.9 & 4.4 & 67.8 & 4.6 & 0.00 & 47.5 & 3.8 \\
\hline 0.12 & 30.2 & 4.8 & $56.2 *$ & 6.3 & 0.005 & 57.2 & 2.5 \\
\hline 0.25 & 31.7 & 2.9 & $59.5 *$ & 3.7 & 0.05 & 51.3 & 4.0 \\
\hline 0.50 & $27.9 *$ & 2.6 & $50.5^{*}$ & 3.7 & 0.12 & 46.6 & 2.7 \\
\hline 1.00 & $26.4 *$ & 2.8 & $47.1 *$ & 3.7 & 0.25 & $39.7 *$ & 3.8 \\
\hline 2.00 & $22.7 *$ & 2.4 & $38.6^{*}$ & 3.3 & 0.50 & $37.2 *$ & 2.2 \\
\hline 4.00 & $19.3^{*}$ & 2.4 & $27.9 *$ & 2.7 & 1.00 & $25.0 *$ & 2.43 \\
\hline
\end{tabular}


estimate that indicated some diminished sublethal but still biologically functional process (Rand Petrocelli, 1995). On the basis of survival, this EC50 estimate places the organism at an extremely tenuous level of existence.

Upon a preliminary exposure of the neonates to doses of: $6,12,24,48,60$, and $120 \mathrm{mg} / \mathrm{L}$ of Round-up for 4 days, no mortality or stress was observed. This observation is not remarkable considering the low toxicities reported for Salmo gairdneri (96 h LC50 $54.8 \mathrm{mg} / \mathrm{L}$ ) and Daphnia pulex (48 h LC50 36 mg/L) (Hellawell, 1986)). Mammalian toxicity has also been reported as very low $(\mathrm{LD} 50=1568 \mathrm{mg} / \mathrm{kg}$ rats oral) (APHA, AWWA and WPCF 1995). In Standard Methods for the Examination of Water and Wastewater, 1995, the toxicological assessment of Round-up is also unalarming, "there is less concern about food and water contamination than with other pesticides".

Though mortality does not seem to be of consequence, the long term ecological significance, albeit less dramatic, may be of far greater consequence. In 4 days, we obtained (Table1) discrete statistically significant growth differences from the control at concentrations of: 0.5, 1.0, 2.0, and $4.0 \mathrm{mg} / \mathrm{L}$. Upon 8 days of exposure, a more pronounced growth inhibition was noted with all dilutions significantly different from that of the controls. Further, the 8 day treatments generated greater "r" values than the 4 day periods (Table 2). The LOEC-NOEC values decreased, respectively, from 0.5 to $0.12 \mathrm{mg} / \mathrm{L}$ and 0.12 to $<0.12 \mathrm{mg} / \mathrm{L}$. When we extended the study to 6 replicates (Table 3), we obtained statistically significant levels of growth inhibition at $0.48 \mathrm{mg} / \mathrm{L}$ in only 4 days and at $0.24 \mathrm{mg} / \mathrm{L}$ in 8 days. The respective 4 and 8 day LOEC/NOEC values would then be $0.48 / 0.24$ and $0.24 / 0.12$. These values are in good agreement with the estimates in Table 2. Upon comparing growth rates among the test concentrations and the controls for any time period, the differences are extremely marked and abrupt. At $0.48 \mathrm{mg} / \mathrm{L}$ after 4 days, the percent increase in growth approached approximately $1 / 4$ that of control. All other test concentrations failed to yield significant growth differences from control or among each other, even

TABLE 2

REGRESSION statistics of data presented in Table 1. Summary Outputs.

\begin{tabular}{|l|l|l|c|}
\hline \multirow{2}{*}{} & \multicolumn{2}{|c|}{ Round-up } & Paraquat \\
\cline { 2 - 4 } & 4 days & 8 days & 4 days \\
\hline Multiple R & 0.953595015 & 0.96830827 & 0.951043565 \\
\hline R Square & 0.909343453 & 0.937620907 & 0.904483853 \\
\hline Adjusted R Square & 0.886679316 & 0.922026133 & 0.880604816 \\
\hline Standard & 1.570834213 & 3.27486901 & 3.945330123 \\
\hline Observations & 6 & 6 & 6 \\
\hline
\end{tabular}

TABLE 3

AVERAGE weights of 6 replicates with 15 specimens/replicate $(\mathrm{mg})$ with confidence intervals and percent increase over initial weights of $P$ lineata neonates exposed to indicated intervals (days) and concentrations ( $\mathrm{mg} / \mathrm{L}$ ) of Round-up.

\begin{tabular}{|c|c|c|c|c|c|c|c|c|c|}
\hline \multirow{3}{*}{$\begin{array}{l}\text { Conc. } \\
(\mathrm{mg} / \mathrm{L})\end{array}$} & \multicolumn{9}{|c|}{ Days } \\
\hline & \multirow{2}{*}{$\begin{array}{c}\mathbf{0} \\
\mathrm{mg}\end{array}$} & \multicolumn{2}{|l|}{4} & \multicolumn{2}{|c|}{8} & \multicolumn{2}{|l|}{12} & \multicolumn{2}{|l|}{16} \\
\hline & & mg & $\%$ & mg & $\%$ & mg & $\%$ & mg & $\%$ \\
\hline 0 & $67 \pm 13$ & $127 \pm 23.1$ & 89.5 & $210 \pm 2.0$ & 213 & $266 \pm 28.4$ & 302 & $317 \pm 29.4$ & 373 \\
\hline 0.60 & $70 \pm 7$ & $133 \pm 7.0$ & 90.0 & $217 \pm 9.5$ & 210 & $270 \pm 19.0$ & 286 & $322 \pm 26.2$ & 360 \\
\hline 1.20 & $69 \pm 5.25$ & $131 \pm 13.8$ & 90.0 & $212 \pm 15.0$ & 207 & $265 \pm 19.0$ & 284 & $305 \pm 26.5$ & 342 \\
\hline 2.40 & $60 \pm 4.19$ & $120 \pm 6.3$ & 100.0 & $183 \pm 15.0$ & $201 *$ & $213 \pm 27.0$ & $255^{*}$ & $257 \pm 47.0$ & $328 *$ \\
\hline 4.80 & $60 \pm 5.2$ & $74 \pm 15.7$ & $23.0^{*}$ & $89 \pm 19.0$ & $48.0 *$ & $96 \pm 21$ & $60 *$ & $* *$ & 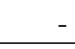 \\
\hline
\end{tabular}

$* * 40 \%$ mortality (survival in all other instances remained above $90 \%$ ). 
after 16 days of exposure. Based on these data the LOEC-NOEC would be $0.24 \mathrm{mg} / \mathrm{L}$ and $0.12 \mathrm{mg} / \mathrm{L}$, respectively. The fact that, in terms of mortality, $P$. lineata appears to be insensitive to extended exposure to high concentrations of Round-up and yet is so responsive with regard to growth supports the value of the protocol as an index of stress.

Such ready inhibition of growth over a short test period may have ecological and public health implications. Pomacea has been identified as an effective biocontrol of Biomphilaria glabrata (intermediate host of the fluke Schistosoma mansoni) through its predation on egg masses and neonates (Paulini \& Paulini, 1971). Any factor that would place this control at a disadvantage could increase the incidence of $B$. glabrata and consequently Schistosoma. This method holds promise to serve as an early warning alarm for herbicide and effluent outfall toxicity (Melo, 2000). By resorting to survival and growth inhibition as endpoints, the investigator is provided with water quality indices whose limits of detection for Paraquat in the receiving waters of the littoral zone fall well within the manufacturer's recommended biweekly application levels of $100 \mathrm{mg} / \mathrm{m}^{2}$ (Medeiros et al., 2001). Further, with regard to Round-up, we are provided with an endpoint in growth that mortality failed to indicate at 30 times the 8 day LOEC level. Biomarkers, as such, are proactive and provide a margin of time to respond to perceived crises.

The method is not without precedence, but what is innovative is the application of snails to routine toxicity testing. Since the mid $80 \mathrm{~s}$, whole effluent toxicity testing (WETT) has assumed a central role in the granting of industrial and domestic sewage discharge permits (Grothe, Dickson and Reed-Junkins, 1995). Adoption of this protocol has been strongly urged by the USEPA to protect the aquatic biota of receiving waters from the adverse affects of waste water effluents. While the Agency recognizes that toxicity testing cannot be substituted for chemical standards, it endorses this procedure as a tool to integrate the effects of all toxic pollutants contained in the outfall (USEPA 1995). Further, it has standardized acute and chronic toxicity testing protocols, employing indigenous biota as surrogate test species (USEPA 1985). Subsequently, it has proposed adoption of this strategy for the routine application for National Pollution Discharge Elimination System Permits (NPDES).
The consistency of the results demonstrates how readily toxicity is identified, the protocol implemented and the data replicated. We therefore urge the routine incorporation of the $P$. lineata toxicity assay into the standard state procedure for evaluating and screening municipal and industrial sewage discharges in fresh water.

\section{REFERENCES}

APHA, AWWA, \& WPCF, 1995, Standard Methods for the Examination of Water and Wastewater, $19^{\text {th }} \mathrm{ed}$. Washington, D.C., American Public Health Association, American Water Works Association, and Water Pollution Control Federation, $2630 \mathrm{p}$.

CALABRESE, E. J. \& BALDWIN, L. A., 1993, Possible examples of chemical hormesis in a previously published study. J. Appl. Toxicology, 13: 169-172.

CEBALlOS, B. S., LIMA, E., KÖNING, A. \& MARTINS, M. T., 1995, Spatial and temporal distribution of fecal Coliforms, Colifages, moulds and yeasts in freshwater at the semi arid tropic northeast Brazil (Paraíba State). Rev. Microbiol., São Paulo, 26: 90-100.

CLEGG, B. S., STEPHENSON, G. R. \& HALL, J C., 1999 , Development of an enzyme-linked immunosorbent assay for the detection of glyphosate. J. Agricultural and Food Chemistry, 47: 5031-5037.

CLEGG, B. S., STEPHENSON, G. R. \& HALL, J. C., 2001, Development of an enzyme-linked immunosorbent assay for the detection of dicamba. J. Agricultural and Food Chemistry, 49: 2168-2174.

COLER, R. A., WATANABE, T. \& XAVIER, B de F. 1999, A preliminary report on the application of Macrobrachium amazonicum Heller, 1862 (Decapoda: Paleamonidae) as a biomarker. Hydrobiologia, Netherlands, 41: 119-121.

GONÇALVES, A. R. R., ABDULHADER, L. Y., MALHEIRO, P., SABBAGA, E., MARCONDES, M. \& URDMAN, E., 1992, Tratamento da intoxicação por Paraquat: de dois casos e revisão da literatura. J. Bras. Nefrol., 14: 12-16.

GROTHE, D. R., DICKSON, K. L. \& REED-JUNKINS, D., 1995, Workshop overview in whole effluent toxicity testing. Chapt. 1: 1-9 In: D. R., Dickson, K. L., \& Reed-Judkins , D. (eds). Whole Effluent Toxicity Testing Goethe, SETAC PRESS, Pensacola, FL. 346 p.

HELLAWELL, J. M., 1986, Biological Indicators of Freshwater Pollution And Environmental Management. Elsevier Applied Science, London, $546 \mathrm{p}$.

MEDEIROS, V. M., WATANABE, T., COLER, R. R. \& COLER, R. A., 2001, Development of methods to assess the impact of herbicide use on the benthos of littoral impoundments in northeast Brazil. J. Aquatic Ecosystem Stress and Recovery, 9: 61-71.

MELO, L. E. L., COLER, R. A., WATANABE, T. \& BATALLA, J. F., 2000, Developing the gastropod Pomacea lineata (Spix, 1827) as a toxicity test organism. Hydrobiologia, 429: 73-78.

MELO, L. E. L., 2000, O uso do Gastropode Pomacea lineata (Spix 1827) como indicador de toxicidade em mananciais 
de água doce no Nordeste do Brasil: Uma preposta metodológica. Universidade Federal da Paraíba. Programa Regional de Pós-Graduação em Desenvolvimento e Meio Ambiente. Dissertação de Mestrado. João Pessoa-PB.

PAULINI, H. M. \& PAULINI, E., 1971, Observações de laboratório sobre controle biológico de Biomphalaria glabrata pela Pomacea sp.(Ampullariidae). Rev. Bras. de Malariologia e Doenças Tropicais, 23: 135-149.

RAND, G. M. \& PETROCELLI, S. R., 1995, Fundamentals of Aquatic Toxicology. MacGraw Hill, Washington DC, $1125 \mathrm{p}$.

ROCHA, T. R., COLER, R., WATANABE, T. \& SASSI, R., 1998, The photosynthetic/respiratory response of a periphytic population (Selanastrum capricornutum) to paraquat as a biomarker. Acta Limnologica Brasiliensis, Brasil, 10(1): 131-136.

UNITED STATES ENVIONMENTAL PROTECTION AGENCY, 1985, Technical support document for water quality-based toxics control. Washington DC: USEPA Office of Water. EPA/440/4-85-032.

UNITED STATES ENVIRONMENTAL PROTECTION AGENCY, 1995, National policy regarding whole effluent toxicity enforcement. Washington DC: USEPA Offices of regulatory enforcement and wastewater management.

WATANABE, T., COLER, R.A. \& PAZ, R.J., 1999, The implementation of a regional biomonitoring program in Northeast Brazil. Aquatic Ecosystem Health and Management, 2: 187-189. 